\title{
Effect of supplemental energy intake on growth rate of suckling quarter horse foals
}

\author{
L. H. Breuer', R. A. Zimmerman' and J. D. Pagan² \\ 1 Purina Mills, Inc., St. Louis, MO \\ ¿Kentucky Equine Research, Inc., Versailles, KY
}

\begin{abstract}
Summary
Studies of mares and foals maintained in drylot conditions indicated that foals need to be supplemented with 15-20 MJ DE/d at 2-3 months of age to obtain weight gains acceptable in commercial horse operations. Acceptable rates of gain were obtained in 3-6 month old foals receiving $27 \mathrm{MJ}$ DE/d of supplemental energy while maintained on pasture with their dam. Calculations indicate that these foals were likely consuming pasture dry matter at a rate of at least $1 \%$ of BW. Another study showed that no supplemental energy was needed in foals up to 4 months of age when mares and foals were maintained on high quality pasture.
\end{abstract}

keywords: $\quad$ horses, growth, nutrition, energy

\begin{abstract}
Wirkung einer zusätzlichen Energiegabe auf die Wachstumsrate von Quarterhorsefohlen
Untersuchungen bei Stuten und Fohlen in grasfreier Auslaufhaltung zeigten, daß diese Fohlen im Alter von 2-3 Monaten mit 15-20 MJ DE/Tag supplementiert werden müssen, um für kommerzielle Pferdehaltungen adäquate Zunahmen zu erreichen. Ausreichende Gewichtszunahmen wurden bei Fohlen im Alter von 3-6 Monaten, die mit ihren Müttern auf der Weide waren, bei zusätzlicher Aufnahme von 27 MJ DE/Tag erreicht. Indirekte Berechnungen zeigen, daß diese Fohlen mindestens 1\% ihres Körpergewichtes an Trockensubstanz des Weidegrases aufnahmen. Eine weitere Studie ergab, daß bei Fohlen bis zu 4 Monaten keine zusätzliche Energieaufnahme erforderlich war, wenn Stuten und Fohlen auf einer hochwertigen Weide grasten.
\end{abstract}

Schlüsselwörter: Pferde, Wachstum, Ernährung, Energie

\section{Introduction}

Foals grow to over $80 \%$ of mature wither height and $50 \%$ of mature body weight by 6 months of age under good US horse management systems (Hintz et al. 1977; Thompson 1995). Yet information is lacking on the energy contribution made by mare milk and pasture or hay in meeting the total energy requirement of the rapidly growing foal. Such information is needed to properly supplement the growing foal for rapid growth or to control growth to deal with developmental disorders. These studies were carried out to evaluate the effects of feeding supplemental energy on growth of Quarter Horse foals up to 6 months of age.

\section{Experimental procedures}

Experiment 1. A total of 164 Quarter Horse mare and foal pairs were studied over a period of seven years at the Purina Horse Research Center. The mares weighed $475-575 \mathrm{~kg}$ and were maintained with their foals in individual stalls. Mares and foals were turned out in exercise lots for 6-7 hours daily. The mares were individualiy fed a complete pelleted feed twice daily and had free access to water. The mare feed was an alfalfa based pellet formulated to contain 9.5-10.5 MJ DE/kg and fed at levels which supported lactation and mare weight gains of $0.1-0.6 \mathrm{~kg} / \mathrm{d}$. Mare intake of energy, protein, and other nutrients met or exceeded NRC (1989) requirements for lactating mares during 3 months following foaling. The foal feed was a $16 \%$ protein, grain and soybean meal based feed containing approximately $12.9 \mathrm{MJ} \mathrm{DE} / \mathrm{kg}$. The foal feed was offered free-choice in individual foal feeders beginning at 35 days of age and continued for eight weeks. The foals were weighed weekly and individual daily feed intakes were recorded. Experiment 2. A total of 28 Quarter Horse foals were studied over a two year period at the Purina Horse Research Center. Half of the foals were weaned at 3 months of age and half of the foals were left with their dam on pasture for an additional 3 months. The early weaned foals were maintained in pairs in stalls and turned out in exercise lots daily. The early weaned foals were given free access to a $16 \%$ protein, complete pellet containing approximately 11.6 MJ DE $/ \mathrm{kg}$. Foals left with mares were given free access to a $16 \%$ protein, grain based pellet containing approximately $12.9 \mathrm{MJ} \mathrm{DE} / \mathrm{kg}$. Mares and suckling foals were maintained on excellent quality grass pastures and mares received grain based supplements furnishing a range of 30-60 MJ DE/d. Foals were weighed monthly and feed consumption was recorded daily.

Experiment 3. Eleven pairs of Quarter Horse mares and foals were studied at the Purina Horse Research Center. They were maintained on excellent quality grass pasture for four months beginning 7 days after foaling. Five mares received pasture only and 6 mares were fed a $13 \%$ protein grain supplement to furnish approximately $60 \mathrm{MJ} \mathrm{DE} / \mathrm{d}$. The foals were not supplemented but some had an opportunity to eat with mares which were being supplemented and all foals had unlimited access to pasture. Mares and foals were weighed monthly and feed consumption recorded daily. Pasture samples were taken monthly and 
analyzed for protein, crude fiber, calcium, and phosphorus using AOAC (1975) methods.

\section{Results and discussion}

Experiment 1. The 164 Quarter Horse foals gained an average of $1.1 \mathrm{~kg} / \mathrm{d}$ from 35 to 91 days of age and consumed an average of 12.7 MJ DE/d from supplemental feed. There was sufficient variation in DE intake and weight gain in the foals to allow regression of foal weight gain against supplemental DE intake. Regression analysis gave the following equation:

Foal gain $(\mathrm{kg} / \mathrm{d})=0.95+0.012$ [foal supplement $\mathrm{DE}(\mathrm{MJ} / \mathrm{d})$ ]

Using this equation, no supplemental feeding would result in a gain of $0.95 \mathrm{~kg} / \mathrm{d}$ which is the foal gain supported by milk alone from mares fed in drylot to gain body weight during lactation. Studies of weight gains of 2-3 month old Thoroughbred foals under practical farm conditions by Hintz et al. (1979) and Thompson (1995) showed weight gains of about $1.2 \mathrm{~kg} / \mathrm{d}$. The equation indicates 2-3 month old foals will need an additional 20.8 MJ DE to gain $1.2 \mathrm{~kg} / \mathrm{d}$. The additional energy would have to furnished by either dry feed or some combination of dry feed and pasture in pastured animals.

Tab. 1: Performance of suckling and weaned foals from 3 to 6 months of age (Experiment 2).

Entwicklung von nicht-abgesetzten und abgesetzten Fohlen im Alter von 3-6 Monaten

\begin{tabular}{|l|c|c|}
\hline & Suckling foals & Weaned foals \\
\hline No. of foals & 14 & 14 \\
\hline Weight gain $(\mathrm{kg} / \mathrm{d})$ & 1.14 & 1.05 \\
\hline Wither height gain $(\mathrm{cm})$ & 9.4 & 9.9 \\
\hline Feed intake $(\mathrm{kg} / \mathrm{d})$ & 2.1 & 6.0 \\
\hline Feed DE intake $(\mathrm{MJ} / \mathrm{d})$ & 27.1 & 69.6 \\
\hline
\end{tabular}

Experiment 2. Data in Table 1 show that suckling foals gained $1.14 \mathrm{~kg} / \mathrm{d}$ from 3 to 6 months of age while early weaned foals gained $1.05 \mathrm{~kg} / \mathrm{d}$ (nonsignificant). Wither height gain was also similar for both groups. Daily weight gains for these foals were similar to those of the younger foals in Experiment 1. These older suckling foals consumed an additional $14 \mathrm{MJ} D E$ as supplemental feed. Based on the DE intake of the weaned foals, the suckling foals must have obtained at least an additional $42.5 \mathrm{MJ}$ DE from mare milk and pasture. Assuming mare milk contains about $2 \mathrm{MJ}$ $\mathrm{DE} / \mathrm{kg}, 21 \mathrm{~kg}$ of milk would be required to furnish all the additional DE. Since such a level of milk production is unlikely, especially in late lactation, foals must have obtained significant amounts of $D E$ from pasture. Calculations indicate that foals would need to consume pasture dry matter at a rate of $1 \%$ of body weight or more to obtain the DE necessary for the observed weight gains.

Experiment 3. Supplementing lactating mares on pasture with an additional 59.34 MJ DE had no significant effect on mare or foal performance (Tab. 2). The absence of an effect on mare or foal weight changes from supplementing pasture indicates that supplemental DE simply replaced pasture DE in the mare's ration.
Tab. 2: Effect of mare supplemental feed on mare and foal performance (Experiment 3).

Wirkung einer Supplementierung der Stute auf die Entwicklung von Stute und Fohlen

\begin{tabular}{|l|c|c|}
\hline & Unsuppl. & Suppl. \\
\hline No. mare and foal pairs & 5 & 6 \\
\hline Mare suppl. DE intake $(\mathrm{MJ} / \mathrm{d})$ & 0 & 59.34 \\
\hline Mare weight gain $(\mathrm{kg} / \mathrm{d})$ & 0.30 & 0.37 \\
\hline Foal weight gain $(\mathrm{kg} / \mathrm{d})$ & 1.26 & 1.33 \\
\hline Foal wither ht. gain $(\mathrm{cm})$ & 26.3 & 26.8 \\
\hline
\end{tabular}

Weight gains of both groups of foals were excellent and appear to be equivalent to those of foals of similar ages reported by Hintz et al. (1979) and Thompson (1995).

The pasture was made up of brome grass and mixed clovers grown under near ideal conditions of fertility, rainfall, and temperature. Analyses of samples taken during the growing season are shown in Table 3. The pasture contained a high level of digestible protein and energy throughout the study. The maintenance of high nutritional value into the summer was likely the result of clovers increasing in the pasture mix as the grass matured.

Tab. 3: Analyses of pasture samples taken during growing season (Experiment 3) (a)

Analyse von Weideproben während der Wachstumsphase

\begin{tabular}{|c|c|c|c|c|}
\hline Date & $\begin{array}{c}\text { Protein } \\
(\%)\end{array}$ & $\begin{array}{c}\text { Fiber } \\
(\%)\end{array}$ & $\begin{array}{c}\text { Calcium } \\
(\%)\end{array}$ & $\begin{array}{c}\text { Phosphorus } \\
(\%)\end{array}$ \\
\hline May 1 & 25.1 & 19.0 & 0.36 & 0.45 \\
\hline June 1 & 12.0 & 28.4 & 0.34 & 0.41 \\
\hline July 1 & 13.0 & 25.4 & 0.46 & 0.35 \\
\hline
\end{tabular}

(a) Values are averages of 3 samples taken at each date expressed as $90 \%$ dry matter basis.

These studies indicate that under conditions where mares and foals do not have access to high quality pasture or forages, foals need supplemental energy by $2-3$ months of age to gain at acceptable rates. At the age of 3-6 months, all foals are likely to need some supplemental energy to continue to gain at rates of $1.0-1.1 \mathrm{~kg} / \mathrm{d}$. The amounts to feed will depend on the availability of high quality pastures or hay. Since older foals may consume large quantities of forage, it is very important to consider the nutrient content of forages in balancing rations for young foals.

\section{References}

AOAC (1975): Official Methods of Analysis, Association of Official Analytical Chemists, Washington, DC.

Hintz, H. F., Hintz, R. L. and Van Vleck, L. D. (1979): Growth rate of Thoroughbreds: Effect of age of dam, year and month of birth. J. Anim. Sci. 48:480.

NRC (1989): Nutrient Requirements of Horses (5th Ed.). Nutrient Requirements of Domestic Animals. National Research Council. National Academy Press. Washington, DC.

Thompson, K. N. (1995): Skeletal growth rates of weanling and yearling Thoroughbred horses. J. Anim. Sci. 73:2513. 